\title{
Devonian Clay Modification for the Improvement of Heavy Metal Sorption Properties
}

\author{
Juris Burlakovs, Julija Karasa, Maris Klavins, University of Latvia
}

\begin{abstract}
Contamination with heavy metals is an important problem as bioaccumulation effects of those are creating direct and indirect hazards to environment and human health. Contaminated soil remediation can be done by various technologies and the use of soil amendments is one. Clay modification experiments were done to study heavy metal sorption from spiked solutions and leaching from contaminated soils. The aim of this paper is to give an overview of Devonian clay modification possibilities in order to improve heavy metal sorption capacity and immobilization options. Modification was done by using $\mathrm{Ca}$, $\mathrm{Na}$ salts, $\mathrm{HNO}_{3}$ (protonated forms), $\mathrm{Fe}$ oxyhydroxide. Research has shown better sorption due to improved properties of clay through the process of modification. Kinetic experiments have shown good results of $\mathrm{Pb}$ removal by using $\mathbf{C a C l}_{2}$ modified clays as the sorption capacity increases comparatively to raw and other types of modified clay. Modified clay as amendments in spiked soils also show negligible improvement of heavy metal immobilization properties comparably to raw Devonian clays. More detailed further research in order to prove batch experimental results should be done in the future.
\end{abstract}

Keywords - remediation, immobilization, contamination, clay, groundwater and soil quality.

\section{INTRODUCTION}

The quality of soil and groundwater is fundamentally important and different technologies are used for the remediation of diffuse and point sources generated by industrial as well as natural contamination. Development of soil and groundwater remediation technologies is a matter of great importance to eliminate historically and currently contaminated sites as contamination causes loss of land as a resource [1]. Heavy metals are toxic and hazardous for human health and environment; sources are natural processes as volcanoes and erosion of rocks as well as anthropogenic sources as industry, mining, diffuse air pollution precipitation and other [2]. Toxic heavy metal ions are non-biodegradable and tend to accumulate in living organisms, causing severe disorders and diseases [3-5]. Overexposure to heavy metals including lead promotes the development of many occupational illnesses. Occupational Safety and Health Administration (OSHA) introduced a five-year strategic plan in order to diminish the hazardous impact of lead on employees by $15 \%$. As this is a question of concern for threats not only directly to people's health and environment in general, sources of industrial and natural pollution should be analyzed and prevented [6]. There are several physicochemical methods available for heavy metal ion removal from aqueous solution, including chemical precipitation, reverse osmosis, filtration, solvent extraction, electrodeposition, electrodialysis, ion exchange and adsorption, etc. $[4 ; 7 ; 8-12]$. Among these methods, adsorption is considered as an effective method for heavy metal ion removal from aqueous solution due to its cost-effectiveness and high efficiency $[3 ; 11]$. Soil amendments often can be used as one of the in-situ technologies for the rehabilitation process of contaminated soil. Besides the mining and metal related industries, other sources are metal-laden effluents as leather tanning, batteries, glassware, ceramics, electroplating, paint and photographic industry residuals [13]. Fate of heavy metals including lead is affecting food chains, not only human [14]. Natural zeolites are not as good as synthetic ones, but clay minerals in many cases can be used as good sorbents for heavy metal removal, wastewater can be treated much cheaper with a good efficiency [15]. Zeolite (clay) is a class of alkaline porous alumo-silicate, with a negative charge [16], neutralized by introducing exchanged cations in the structure sites itself $[17 ; 18]$. Zeolites are being developed, because those are diminishing the solubility and thus the biological availability of metals: salts and complexes, also oxides and metalcarbonate precipitates are formed [19;20]. Research nowadays is concentrated to zeolites as effective treatment agents because of lower costs of them, sorbents as natural and modified clay can be used for groundwater and wastewater treatment from arsenic, tungsten, uranium, selenium, lead and many other elements with toxic impact properties [21]. Comparatively a lot of research has been dedicated to organomodified clays and surface modified clays, described in review [22]. Acidic treatment can be one of the solutions [23]. Calcium and magnesium is removed, iron and aluminium content of clay minerals are partially removed. Chemical composition through hydrothermal reactions in acidic solutions is changing together with the mineralogical structure of clay minerals. Montmorillonic clays can be more effectively treated compared to kaolinic ones [24]. Sometimes sorption capacity diminishes during acidic treatment [25]. Surface area and pore volume in montmorillonite can diminish when acidic treatment is applied [26]. The mass of clay also decreases by 25-30\% through this type of treatment. Devonian clays used in these series of batch tests as soil amendment were studied in [27], where stability constants of ligands were studied considering the contamination of copper in soils. This study was dedicated to clay modification by nitric acid as well as $\mathrm{Ca}$ and $\mathrm{Na}$ salts in order to prepare surface modified forms and their potential towards nickel $[\mathrm{Pb}(\mathrm{II})]$ sorption considering the ion exchange mechanism. Lead was selected as a model pollutant as its salts are used in many industrial applications. $\mathrm{Pb}$ (II) is not essential for living organisms and long term 
exposure to higher $\mathrm{Pb}(\mathrm{II})$ concentrations may lead to various health problems of carcinogenic and teratogenic character included. The sorption kinetics on raw and modified clay was examined and the role of functional groups in $\mathrm{Pb}$ (II) sorption was discussed based on the data obtained from Fourier transform infrared spectral (FTIR) analysis and other studies.

The aim of this work is to evaluate the use of natural modified zeolites which can be possibly used for remediation of soil and waters contaminated with heavy metals (sewage or groundwater). Improvement of modified clay sorption properties in aquatic phase would show the potential and efficiency of use of innovative materials in remediation industry.

\section{MATERIALS AND METHODS}

\section{A. Soil samples for leaching experiments}

Mineral soil samples were collected in field works from 10 soil profiles of varied soil granulometric composition or soil texture, composition and properties are described in previous studies [28]. Devonian zeolite (clay) amendments are taken from the Lode quarry in the northern part of Latvia, these clays are made of illite with significant content of kaolinite.

\section{B. Modification of Devonian clay}

Devonian clay was modified by iron oxide-hydroxide. For $\mathrm{Fe}(\mathrm{OH})_{3}$ preparation $250 \mathrm{~mL}$ of $0.25 \mathrm{M}$ and $0.5 \mathrm{M} \mathrm{FeCl}{ }_{3} \cdot 6 \mathrm{H}_{2} \mathrm{O}$ were amended with $250 \mathrm{~mL}$ of $3 \mathrm{M} \mathrm{NaOH}$ for three hours. Washing and decanting was repeated three times and $100 \mathrm{~g}$ Devonian clay was mixed in $\mathrm{Fe}(\mathrm{OH})_{3}$ dispersion. Mixing, filtration and washing with deionised water is repeated, the drying for $12 \mathrm{~h}$ is done at room temperature, at the end the drying is fulfilled to the end in Gallenkamp Plus II oven for $4 \mathrm{~h}$ in temperature $60^{\circ} \mathrm{C}$.

\section{Samples preparation for leaching tests}

Afterwards samples were sieved again and weighted for two different procedures: 10 different samples of soil were taken, 10 were amended with $10 \%(\mathrm{~m} / \mathrm{m})$ of raw Devonian Lode clay, $10 \%(\mathrm{~m} / \mathrm{m})$ Devonian modified clay with $5 \% \mathrm{FeOOH}$ and $10 \% \mathrm{FeOOH}$, respectively. All 40 samples were spiked with lead nitrate in order to apply known contamination of $100 \mathrm{mg} \mathrm{kg}^{-1}$ in those.

\section{Leaching tests.}

During the batch leaching test vessels were filled with distilled water till a liquid-to-solid-ratio 10:1 (referred to the dry sample). Under continuous agitation at the rate 130 RPM (Grant OLS200) the batch leaching test was done for samples with agitation time periods of 24 hours. The $\mathrm{pH}_{\mathrm{H} 2 \mathrm{O}}$ level was measured for all samples after each period using Beckmann $\mathrm{pH}$ meter 340. After this time the solution is let to set down for about 10 minutes. For the determination of inorganic compounds the solution was filtered through a $0,45 \mu \mathrm{m}$ filter. The concentration of $\mathrm{Pb}$ in the leached eluate was determined by Atomic Absorption Spectrometer (AAS) (GBC 932 Plus, Perkin Elmer) with deuterium background correction and a spectral slit width of $0.5 \mathrm{~nm}$ for $\mathrm{Pb}$ and wavelength $283.31 \mathrm{~nm}$.

\section{E. Kinetic experiments}

Modification of Devonian Lode clay was carried out in several ways to compare results of sorption. First type of modification was protonation of the clay $-5 \mathrm{~g}$ of raw clay was added in $500 \mathrm{~mL}$ of $0.2 \mathrm{M} \mathrm{HNO}_{3}$ solution, second type $-5 \mathrm{~g}$ of sorbent was added in $500 \mathrm{~mL}$ of $0.5 \mathrm{M} \mathrm{CaCl}_{2}$, the third $-5 \mathrm{~g}$ of sorbent was added in $500 \mathrm{~mL}$ of $0.5 \mathrm{M} \mathrm{NaCl}$. Kinetic experiments were performed with $100 \mathrm{mg} \mathrm{l}^{-1}$ lead solution with $\mathrm{pH}$ adjusted at 5-5.1. Modified clays were dried in Gallenkamp Plus II at temperature $45^{\circ} \mathrm{C}$ for $8 \mathrm{~h}$ (Fig.1).

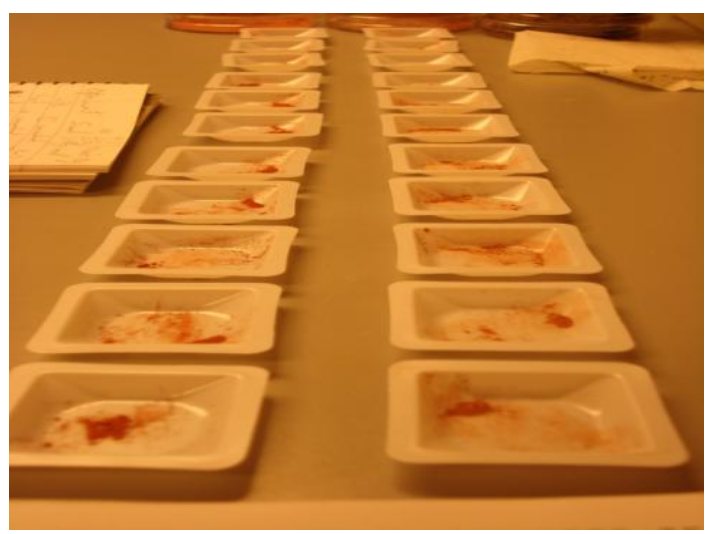

Fig. 1. Modified Devonian clay - Na modified and Ca modified for sorption kinetics tests at Linnaeus University laboratory

Operating in batch mode at room temperature $0.025 \mathrm{~g}$ of every type of modified clay sorbent was added to each flask for kinetic experiments. The solution $\mathrm{pH}$ was maintained at 5.0 throughout these experiments. Experiments were carried out in $50 \mathrm{~mL}$ capped Erlenmeyer flasks containing $50 \mathrm{~mL} \mathrm{~Pb}$ (II) solution and $0.025 \mathrm{~g}$ raw and modified clays by shaking (130 rpm) (Grant OLS200) at $22^{\circ} \mathrm{C}$ various time periods of $5,10,15,30,60,120,180,240,300,360,480$ and 1440 minutes. After adjusting the $\mathrm{pH}$, no further adjustments were performed and final $\mathrm{pH}$ was documented after experiments. After achieving equilibrium, solutions were separated by filtration through cellulose acetate membrane and analyzed for residual lead content by atomic absorption spectrometry (AAS).

\section{RESUlTS AND DisCUSSION}

\section{A. Leaching experiment results.}

Leaching experiment was performed in order to simulate processes in widely distributed soils in Latvia under natural conditions in batch mode without impacts of heavy rains or acid precipitation. One set of experiment is showing leaching from raw soil.

The $\mathrm{pH}_{\mathrm{H} 2 \mathrm{O}}$ values of all samples were essentially of natural neutral conditions 5.0-6.7 and during the agitation $\mathrm{pH}_{\mathrm{H} 2 \mathrm{O}}$ was increasing or not significantly changing in all cases, this trend is dictating the behaviour of lead during the leaching experiment. Table I depicts results of leaching from soils of different texture, where there are: no amendments added, raw 
Devonian clay added, and two different types of modified clay with $\mathrm{FeOOH}$ added. Results show that lead ions are immobilized more when more clay to soil is added thus proving general hypothesis of heavy metal ion immobilization in soils with higher cation exchange capacity. General trends in the table are that soils with higher content of aleiritic and clayey particles with no amendment diminish the leaching of lead under natural $\mathrm{pH}$ conditions. If the contents of clayey particles are proportionally increased in the sample, then even less leaching of lead happens. There is little increase of immobilization of lead ions in soil if modified Devonian clay is added with $\mathrm{FeOOH}$. Immobilization efficiency increases by $5-10 \%$, but more advanced experimental work must be applied to prove first pilot results. There is no significant change of immobilization efficiency if more $\mathrm{FeOOH}$ is applied in the clay, also the slight differences of results in the experiment with values less than $1 \mathrm{mg} \mathrm{L}^{-1}$ can happen under the influence of many circumstances as homogeneity of samples, small scale clay mineral dispersion in various samples, modification irregularities and many more. However, in general leaching of lead from spiked samples with $100 \mathrm{mg} \mathrm{kg}^{-1}$ contamination is diminished when Devonian clay is amended and efficiency increases if modified Devonian clay with $\mathrm{FeOOH}$ is applied. Benefits of Devonian clay modification with $\mathrm{FeOOH}$ for lead immobilization efficiency improvement under natural $\mathrm{pH}$ conditions are relatively negligible and disputable, therefore other methods for modification should be found for applied environmental soil remediation projects.

\section{B. Kinetic experiments results}

Experimental performance was designed in order to evaluate the sorption of lead from contaminated $100 \mathrm{mg} \mathrm{L}^{-1}$ solution by using three types of Devonian modified clays and comparing them with untreated raw clay. Such types of kinetic experiments are a good indicator of sorption properties for materials, which possibly would help the remediation process in aquatic environment, diminishing deleterious impact of toxic heavy metals to environment by migrating further from the source site. Results of sorption kinetics are provided in
Figure 2, where the raw clay achieves equilibrium sorption in 6 hours, afterwards the effect is insignificant. Sorption of lead onto raw clay achieves $30-35 \mathrm{mg}$ of lead for $\mathrm{g}$ of sorbent under natural conditions. Sodium modified clay achieve higher sorption in the first hour than compared with the raw clay, but the effect is not continuously growing with time.

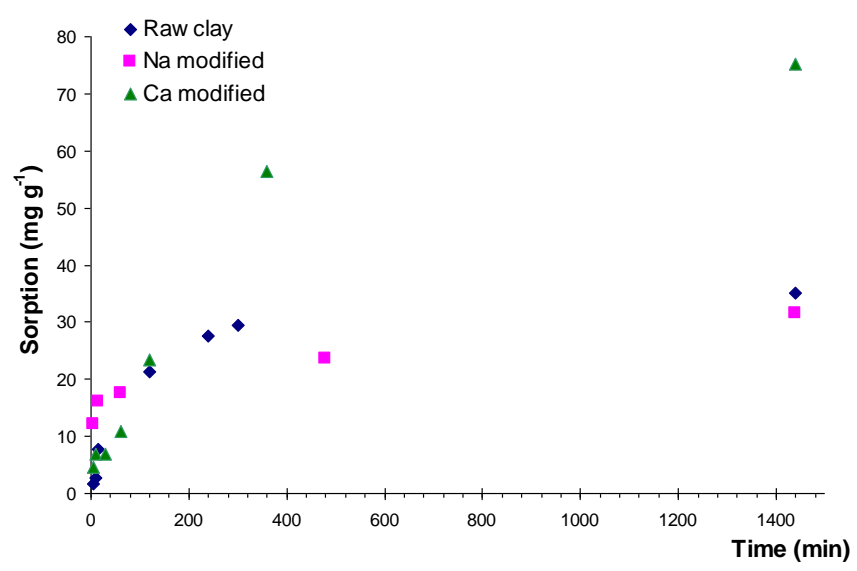

Fig. 2. Lead sorption by Devonian clay raw, Na modified and Ca modified

There is almost no difference for raw and Na modified clay in terms of sorption efficiency in the long term. Protonated forms did not show good results for interpretation thus more detailed analysis should be done in further experimental series; those are not put in a diagram in Fig. 2. It seems that protonation of clay promotes complicated sorption-desorption pair-process and other types of column testing would be a good solution for having more reasonable explanations. The most effective results were yielded from $\mathrm{Ca}$ modified clay testing and the effect is significant. Ca modified clay have growing sorption curve and in $24 \mathrm{~h}$ it reaches around $75 \mathrm{mg} \mathrm{g}^{-}$ 1. Calcium modified clays are reasonable for use as the lead sorption agent for wastewater treatment and can be chosen for further analysis of feasibility in different environmental conditions.

TABLE I

LEACHING EXPERIMENT RESULTS FROM SOILS OF DIFFERENT TEXTURE AMENDED WITH RAW AND MODIFIED DEVONIAN CLAY*

\begin{tabular}{|c|c|c|c|c|c|c|}
\hline $\mathrm{Nr}$. & $\begin{array}{c}\mathrm{pH}_{\mathrm{KCl}} \\
\text { mean value }\end{array}$ & $\begin{array}{l}\text { Soil textural } \\
\text { classes }\end{array}$ & $\begin{array}{l}\text { No amendment } \\
\quad\left(\mathrm{mg} \mathrm{kg}^{-1}\right)\end{array}$ & $\begin{array}{c}10 \% \text { Devonian raw clay } \\
\text { amended } \\
\left(\mathrm{mg} \mathrm{kg}^{-1}\right)\end{array}$ & $\begin{array}{l}\text { 10\% Devonian 5\% FeOOH } \\
\text { modified clay amended } \\
\qquad\left(\mathrm{mg} \mathrm{kg}^{-1}\right)\end{array}$ & $\begin{array}{c}\text { 10\% Devonian } 10 \% \mathrm{FeOOH} \\
\text { modified clay amended } \\
\left(\mathrm{mg} \mathrm{kg}^{-1}\right)\end{array}$ \\
\hline 1 & 4.97 & sandy loam & 1.54 & 0.98 & 1.05 & 1.00 \\
\hline 2 & 5.69 & sandy loam & 1.76 & 1.14 & 0.98 & 0.99 \\
\hline 3 & 4.52 & sandy loam & 1.22 & 0.85 & 0.56 & 0.61 \\
\hline 4 & 4.88 & sandy loam & 2.08 & 1.65 & 1.45 & 1.58 \\
\hline 5 & 6.08 & Loam & 0.45 & 0.53 & 0.44 & 0.48 \\
\hline 6 & 5.10 & Loam & 1.09 & 0.67 & 0.60 & 0.42 \\
\hline 7 & 6.54 & Loam & 0.64 & 0.49 & 0.47 & 0.49 \\
\hline 8 & 5.24 & silt loam & 0.39 & 0.48 & 0.31 & 0.31 \\
\hline 9. & 5.75 & Clay & $<0.2$ & $<0.2$ & $<0.2$ & $<0.2$ \\
\hline 10. & 4.23 & Sand & 2.45 & 1.67 & 1.55 & 1.46 \\
\hline
\end{tabular}

* - leaching mass loss from filtered soil samples which are found in eluates were measured in units mg ${ }^{-1}$, but in Table are given recalculated with rate L:S 10:1 and therefore are given for comparison also in $\mathrm{mg} \mathrm{kg}^{-1}$ by arithmetically multiplying with 10 


\section{CONCLUSIONS}

Two types of different test series for leaching and kinetics were done in order to test lead immobilization properties for various types of Devonian clays modified with $\mathrm{FeOOH}, \mathrm{Ca}$ and $\mathrm{Na}$ salts, $\mathrm{HNO}_{3}$. Leaching tests have shown minor effect of $\mathrm{FeOOH}$ modified clays contaminated with lead soil treatment. Kinetic test have proven that the most effective results for lead sorption from aqueous spiked solution under natural conditions were achieved by using Ca salts for Devonian clay modification. Sorption reached 70-75 mg of lead per gram of sorbent thus the economic feasibility of local Latvian clay use in heavy metals treatment can be foreseen if experiments are done further in detail.

\section{ACKNOWLEDGEMENTS}

This research was carried out with the help of European Social Fund (ESF) and Linnaeus University. Special thanks to Dr. Amit Bhatnagar for the kind help with laboratory work advisory.

\section{REFERENCES}

1. Directive 2008/1/EC of the European Parliament and of the Council of 15 January 2008 concerning integrated pollution prevention and control. Text with EEA relevance. Official Journal of the European Union, L $24 / 8$.

2. Lado, L.R., Hengl, T., Reuter, H.I. Heavy metals in European soils: a geostatistical analysis of the FOREGS Geochemical database. Geoderma, 2008, $148, \quad$ p. 189-199 http://dx.doi.org/10.1016/j.geoderma.2008.09.020

3. Lee, S.M., Laldawngliana, C., Tiwari, D. Iron oxide nanoparticlesimmobilized- sand material in the treatment of $\mathrm{Cu}(\mathrm{II}), \mathrm{Cd}(\mathrm{II})$ and $\mathrm{Pb}$ (II) contaminated waste waters. Chem Eng J, 2012, 195-196, p. 103-111. http://dx.doi.org/10.1016/j.cej.2012.04.075

4. Tong, K.S., Jain Kassim, M., Azraa, A. Adsorption of copper ion from its aqueous solution by a novel biosorbent Uncaria gambir: equilibrium, kinetics, and thermodynamic studies. Chem Eng J, 2011, 170, p. 145 153. http://dx.doi.org/10.1016/j.cej.2011.03.044

5. Yadav, S., Srivastava, V., Banerjee, S., Gode, F., Sharma, Y.C. Studies on the removal of nickel from aqueous solutions using modified riverbed sand. Environ Sci Pollut Res, 2013, Jan 20(1), p.558-567.

6. Occupational Safety and Health Administration (Lead) [Online]. US Department of Labor, [Accessed 17.05.2013.]. Available: http://www.osha.gov/SLTC/lead/

7. Bailey, S.E., Olin, T.J., Bricka, R.M., Adrian, D.D. A review of potentially low-cost sorbents for heavy metals. Water Res. 1999, 33, p. 2469-2479. http://dx.doi.org/10.1016/S0043-1354(98)00475-8

8. Da'na, E., Sayari, A. Optimization of copper removal efficiency by adsorption on amine-modified SBA-15: experimental design methodology. Chem Eng J, 2011, 167, p. 91-98. http://dx.doi.org/10.1016/j.cej.2010.12.005

9. Engates, K.E., Shipley, H.J. Adsorption of $\mathrm{Pb}, \mathrm{Cd}, \mathrm{Cu}, \mathrm{Zn}$, and $\mathrm{Ni}$ to titanium dioxide nanoparticles: effect of particle size, solid concentration, and exhaustion. Environ Sci Pollut Res, 2011, 18, p. 386 395. http://dx.doi.org/10.1007/s11356-010-0382-3

10. Sulaymon, A.H., Ebrahim, S.E., Mohammed-Ridha, M.J. Equilibrium, kinetic, and thermodynamic biosorption of $\mathrm{Pb}(\mathrm{II}), \mathrm{Cr}(\mathrm{III})$, and $\mathrm{Cd}$ (II) ions by dead anaerobic biomass from synthetic wastewater. Environ Sci Pollut Res, 2013, 63(10), p. 2434-2445.

11. Wang, X.J., Liang, X., Wang, Y., Wang, X., Liu, M., Yin, D.Q., Xia, S.Q., Zhao, J.F., Zhang, Y.L. Adsorption of Copper (II) onto activated carbons from sewage sludge by microwave-induced phosphoric acid and zinc chloride activation. Desalination, 2011a, 278, p. 231-237. http://dx.doi.org/10.1016/j.desal.2011.05.033

12. Wu, Y.H., Wen, Y.J., Zhou, J.X., Cao, J.L., Jin, Y.P., Wu, Y.Y. Comparative and competitive adsorption of $\mathrm{Cr}(\mathrm{VI})$, As(III), and $\mathrm{Ni}(\mathrm{II})$ onto coconut charcoal. Environ Sci Pollut Res, 2013, Apr, 20(4), p. 2210-2219. http://dx.doi.org/10.1007/s11356-012-1066-y
13. Brown S.E., Welton, W.C. Heavy Metal Pollution, Nova Science Pub Inc., 2008, 650 p.

14. Kabata-Pendias, A., Pendias, H. Trace elements in soils and plants. 4th ed. 2010, 331 p. http://dx.doi.org/10.1201/b10158

15. Vengris, T., Binkiene, R., Sveikauskaite, A. Nickel, copper and zinc removal from waste water by a modified clay sorbent. Applied Clay Science, 2001, 18, p. 183-190. http://dx.doi.org/10.1016/S01691317(00)00036-3

16. Mohamed, M.M. Heat capacities, phase transitions and structural properties of cation-exchanged H-mordenite zeolites. Thermochim. Acta, 2001, 372, p. 75-83. http://dx.doi.org/10.1016/S0040-6031(01)00433-6

17. Breck, D.W. Zeolite molecular sieves: structure, chemistry and use. Wiley, New York, 1974, 657 p.

18. Mondales, K.D., Carland, R.M., Aplan, F.F. The comparative ion exchange capacities of natural sedimentary and synthetic zeolites. Miner Eng, 1995, 8, p. 535-548. http://dx.doi.org/10.1016/0892$\underline{6875(95) 00015-\mathrm{I}}$

19. Chlopecka, A., Adriano, D.C. Mimicked in-situ stabilization of metals in a cropped soil: bioavailability and chemical form of zinc. Environ Sci Technol, 1996, 30, p.3294-3303. http://dx.doi.org/10.1021/es960072j

20. Querol, X., Alastuey, A., Moreno, N., Alvarez-Ayuso, E., GarciaSanchez, A., Cama, J., Ayora, C., Simon, M. Immobilization of heavy metals in polluted soils by the addition of zeolite material synthesized from coal fly ash. Chemosphere, 2006, 62, p.171-180. http://dx.doi.org/10.1016/j.chemosphere.2005.05.029

21. Bhattacharyya, K.G., Sen Gupta, S. Adsorption of a few heavy metals on natural and modified kaolinite and montmorillonite: a review. Advances in Colloid and Interface Science, 2008, vol. 140, no. 2, p. 114-131. http://dx.doi.org/10.1016/i.cis.2007.12.008

22. Lee, S.M., Tiwari, D. Organo and inorgano-organo-modified clays in the remediation of aqueous solutions: An overview. Applied Clay Science, 2012, 59-60, p. 84-102. http://dx.doi.org/10.1016/j.clay.2012.02.006

23. Ovcarenko, F.D. Gidrofilnost Glin I Glinistych Mineralov. Izd. AN USSR, Kiev ŽRus, 1961 (in Russian).

24. Komarov, V.S. Adsorbcionno-Strukturnije Svojstva Glin Belorusii. Nauka i Technika, Minsk ŽRus, 1970 (in Russian).

25. Pradas, E.G., Sa'nchez, M.V., Cruz, F.C., Viciana, M.S., Perez, M.F. Adsorption of cadmium and zinc from aqueous solution on natural and activated bentonite. J Chem Tech Biotechnol, 1994, 59, p. 286-295. http://dx.doi.org/10.1002/jctb.280590312

26. Ahenach, J., Cool, P., Vansant, E.F. Acid/base treatment of Al-PILC in $\mathrm{KCl}$ solution. Microporous Mesoporous Mater, 1998, 26, p. 185-192. http://dx.doi.org/10.1016/S1387-1811(98)00232-7

27. Burlakovs, J., Klavins, M., Karklina, A. Remediation of soil Contamination with Heavy Metals by Zeolite and Humic Acid Additives. Latvian Journal of Chemistry, 2013, Vol. 51, Issue 4, p. 336341

28. Burlakovs, J., Kasparinskis, R., Klavins, M. Leaching of Contamination from Stabilization/Solidification Remediated Soils of Different Texture. Scientific Journal of Riga Technical University: Environmental and Climate Technologies, 2012, 9, p. 12-16.

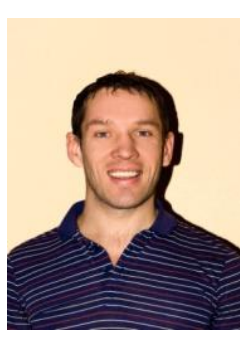

Juris Burlakovs is a doctoral student of Environmental Sciences at the University of Latvia. Particularly the scientific interest is focused on heavy metal contamination remediation technologies and applications of those in different geoecological conditions. Previously he has gained Master degrees in Environmental Management (2009) and Quaternary Geology and Geomorhology (2002) at the University of Latvia, has shortly studied environmental engineering at the University of Padova, Italy and Linnaeus

University, Sweden

$\mathrm{He}$ is a Member of the Board of environmental, geology consultancy and project promotion company Geo IT Ltd. in Riga. Earlier his career is concerned with geomagnetic research and geology.

$\mathrm{He}$ is a member of the Latvian Association for Quaternary Research, Latvian Astronomical Society and European Association of Geoscientists and Engineers.

Address: Alberta Str. 10, LV-1010, Riga, Latvia

E-mail: juris@geo-it.lv 


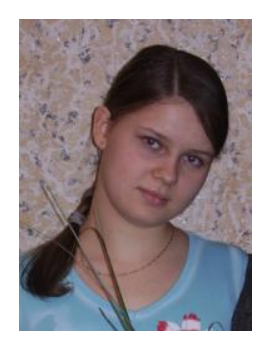

Julija Karasa is a doctoral student of Chemistry programme at the University of Latvia. At present she works as a chemist at the department of Physical chemistry at the University of Latvia. She is also a member of a group focusing on clay minerals chemistry (2009). The main interest of the group is chemical and physical properties of natural and modified clay minerals, particularly montmorillonite saturated clays. She has a Master degree in Analytical / Physical chemistry at the University of Latvia (2012) and is a member of the Association of Latvian Young Scientists.

Address: Kr. Valdemara Str. 48, LV-1013, Riga, Latvia

E-mail: julija.karasa@lu.lv

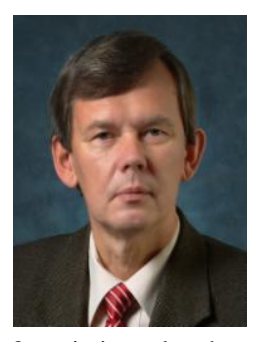

Maris Klavins, professor, Dr.hab.chem, is head of Environmental Science department of Faculty of Geography and Earth sciences, University of Latvia. M. Klavins has worked as head of Laboratory of Sorbents in Institute of Applied Biochemistry of Academy of Sciences USSR, Head of Hydrochemistry group of Institute of Biology and since 1992 is affiliated with University of Latvia. M. Klavins is member of editorial boards of 6 scientific journals, member of 3 societies related to environmental chemistry issues and full member of Academy of Sciences of Latvia. Address: Raina Blvd. 19, LV-1586, Riga, Latvia

E-mail: maris.klavins@1u.1v 